\title{
Efter sekulariseringen: förändrade religiösa värden mellan generationer
}

\author{
MAGNUS HAGEVI
}

"... rich societies are becoming more secular..."

Så sammanfattar statsvetarna Pippa Norris och Ronald Inglehart (2004 s. 217) sin världsomfattande studie om religiositet över nästan hela jordklotet. I den undersökningen framkommer att den svenska befolkningen lever $i$ ett av världens mest sekulariserade samhällen. Sekularisering kan förstås som en förändring över tid: allt eftersom minskar religionens betydelse inom allt fler områden för allt fler människor (Demker 1998, jfr. Dobbelaere 1999). Men denna utveckling kan även antas äga rum mellan generationer: för varje generation ökar sekulariseringen.

Utifrån sina frågeundersökningar från jordens alla hörn konstaterar Norris och Inglehart att befolkningen i Nordeuropas protestantiska länder har extrem låg religiositet sedan 1980-talet. Någon minskning från denna låga religiositet förekom-

Magnus Hagevi, fil.dr. i statskunskap, universitetslektor med inriktning på svensk och jämförande politik, Institutionen för samhällsvetenskap, Växjö universitet. mer knappast, varför författarna antar att sekulariseringen har nått sitt golv (Norris \& Inglehart 2004 s. 73). Tanken att sekulariseringen kan nå ett golv stämmer illa med deras slutsats att rika länder - som samhällena i norra Europa är ett globalt exempel på - sekulariseras allt mer. Vad som händer när sekulariseringen tar slut diskuteras nästan inte alls.

Norris och Ingleharts vilja att undersöka religiösa förändringar tycks ha tagit slut samtidigt med sekulariseringen. I de samhällen som de uppfattar vara "färdigsekulariserade» verkar de även tro att utvecklingen kommit till sin slutstation och ingenting mer händer. De generationer som växer upp i sådana extremt sekulariserade samhällen antas ha samma inställning till religion som sin föräldrageneration. Reli-

1 Denna studie genomförs med stöd av Centrum för studier av institutionell utveckling och värden (CIDV), Växjö universitet. Artikeln bygger delvis på studier som publicerats $\mathrm{i}$ Hagevi 2002, 2007. 
giositet - $\mathrm{i}$ betydelsen individens subjektiva perception av en transcendent verklighet antas således inte förändras i extremt sekulariserade samhällen. Författarparet går så långt att de insinuerar att religionsstudier inte längre behöver genomföras i Nordeuropa, utan att framtida forskningsutmaningar ligger utanför de mest ekonomiskt välutvecklade, postindustriella, länderna (Norris \& Inglehart 2004 s. 240).

Är det en rimlig beskrivning av religiositeten i de generationer som växt upp i ett extremt sekulariserat samhälle? Sekularisering rör religion. Det är vanligt att beskriva religion som trossystem och beteenden vilka är relaterade till en perception av en transcendent verklighet som förenar dem som underkastar sig den i en gemenskap (Dobbelaere 1981 s. 93, jfr. Pettersson 2009, Woodhead \& Heelas 2000). Utifrån Sverige som ett fall av ett extremt sekulariserat samhälle är avsikten att i denna artikel undersöka förändrad religiositet mellan fyra generationer under åren 1986-2008. Detta för med sig två frågeställningar. För det första är det behövligt att veta vilka generationer som främst påverkas av ett extremt sekulärt samhälle. Därför berör den ena frågeställningen vilka generationer har växt upp i ett extremt sekulariserat samhälle. För det andra är avsikten att studera om religiositeten bland dem som växt upp i ett extremt sekulariserat samhälle, det vill säga om religiositeten hos individerna, kan sägas ha ökat eller minskat. Därför är den andra frågeställningen i vad mån personer med olika generationstillhörighet uppvisar olika omfattning av religiositet.

\section{Postmaterialistisk religiositet?}

I början av 1970-talet började Ronald Inglehart arbeta på sin betydelsefulla och omdiskuterade teori om värdeförskjutningar mellan generationer i postindustriella samhällen. Inglehart kallar personer som prioriterar värden relaterade till lag och ordning samt ekonomisk tillväxt för materialister. De som han kallar för postmaterialister värderar i högre grad icke-materiella värden som självförverkligande, tillhörighet, medbestämmande och god miljö. Bland annat menar Inglehart att ett minskat intresse för religion hos den yngre generationen - vilket i Ingleharts genombrottsbok The Silent Revolution var det samma som personer födda på 1940-och 1950-talet - innebar att religionens inflytande på enskilda personers politiska uppfattningar var i avtagande (Inglehart 1977).

I senare publikationer utvecklar Inglehart sin teori om postmaterialistiska värderingar och religion. Han framhåller återigen att religion i form av traditionell kristendom tappar mark i samhället till förmån för postmaterialistiska värden. Enligt Inglehart ifrågasätter allt fler religionens funktion av att ge normer för hela samhället. Han menar att människor ställer existentiella frågor medan många kyrkor med stor emfas försöker upprätthålla de normer och riter som många människor uppfattar som irrelevanta. Samtidigt har dessa människor kvar sina religiösa behov.

"[I]t seems clear that an intergenerational shift is taking place from Materialist toward Postmaterialist values... [T] he available evidence strongly suggests that we are witness- 
ing an intergenerational decline in the subjective importance of God... Postmaterialists are significantly less likely to say they believe in God" (Inglehart 1990 s. 186, 188, 192, Ingelhart 1997).

Han menar dock att det är ironiskt att postmaterialisterna känner främlingskap inför religionerna.

"Postmaterialists have more potential interest in religion than Materialists. But, it would seem, most organized religions today have little to say about the meaning and purpose of life-at least in terms that are meaningful to the Postmaterialists" (Inglehart 1990 s. 192-193, Ingelhart 1997).

Samtidigt avfärdar inte Inglehart betydelsen av religion. Istället menar han att "spiritual concerns are an inherent concern of human beings" (Inglehart 1990 s. 180, Ingelhart 1997, Inglehart \& Welzel 2007 s. 31). Han är inte ensam om ett sådant antagande. Flera religionssociologer arbetar utifrån tanken att en individs religiösa efterfrågan är konstant, men att detta behov kan tillfredsställas på olika sätt. De religiösa förändringarna rör inte människornas religiösa behov utan enbart i vad mån det religiösa utbudet kan tillfredsställa det (Iannaccone \& Finke 1997). Inglehart menar dock att postmaterialisternas religiösa behov inte tar sig uttryck i traditionell religion, utan mer i en öppen attityd till livsåskådningar. Tillsammans med den tyske statsvetaren Christian Welzel skriver Inglehart till och med om ökad religiositet: »There is a shift from institutionally fixed forms of dogmatic religion to individually flexible forms of spiritual religion... Spiritual concerns regain salience" (Inglehart \& Welzel 2007 s. 31-32).

Ingleharts mest utvecklade resonemang om värdeförändringar mellan generationer och individers religiositet återfinns i Sacred and Secular: Religion and Politics Worldwide (2004) som han skrivit tillsammans med statsvetarkollegan Pippa Norris. Angående sekulariseringen sammanfattar de sina resultat på följande sätt:

"This book demonstrate that, with rising levels of existential security, the publics of virtually all advanced societies have been moving towards more secular orientations during the past fifty years" (Norris \& Inglehart 2004 s. 240).

Denna slutsats bekräftar deras arbetshypotes att människor som under uppväxttiden har erfarenhet av säkra samhällen - utan våld och med omfattande välfärd kommer att uppfatta en minskad betydelse av religion och religiösa värden samt därför i mindre utsträckning be till Gud, besöka kyrkor och liknande.

Inglehart grundar sitt arbete på vad han och andra kallar moderniseringsteori (detta framgår tydligast i Inglehart \& Welzel 2007). Moderniseringsteorin antar bland annat att samhällets utveckling ökar sekulariseringen. Enligt denna teori har religion i förindustriella jordbrukssamhällen upprätthållit vissa funktioner, till exempel att ge trygghet. Dels på ett psykologiskt plan, dels materiellt till exempel genom att till stor del handha samhällets fattig- och sjukvård. När samhället moderniseras tas dessa uppgifter över av specialister samtidigt som välfärden utvecklas till att vara mer omfattande och avance- 
rad. Men ekonomisk utveckling är endast ett nödvändigt, men inte ett tillräckligt villkor för sekularisering. Till detta kommer, enligt Norris och Inglehart, att utvecklingen minskar individens oro över existentiella förhållanden, samtidigt som religiösa institutioner förlorar sina materiella trygghetsfunktioner. Enligt moderniseringsteorin minskar därmed också behovet av religion, individernas religiositet avtar och religionen tappar mark inom allt fler områden i samhället (Norris \& Inglehart 2004 s. 9, 18-21). Om moderniseringsteorin är korrekt, menar Norris och Inglehart att sekulariseringen borde ha gått snabbast och längst i överflödssamhällen som har utvecklat omfattande välfärdsstater "such as Sweden..." (Norris \& Inglehart 2004 s. 10).

Efter att ha genomfört ett ansenlig studie av deras omfattande datamaterial drar Norris och Inglehart slutsatsen att religiösa aktiviteter i form av bön och kyrkobesök samt religiös tro minskar med ökat ekonomiskt välstånd och en känsla av säkerhet. På ett par sidor reflekterar de även kortfattat om andligheten bland dem som växer upp i ett postsekulärt samhälle. De menar att vid sidan av den ökade sekulariseringen i form av minskat intresse för traditionell religiositet finns en tendens som visar på ett ökat intresse för individualiserad andlighet. Norris och Inglehart åberopar den del av sina undersökningar som visar att allt fler i postindustriella samhällen funderar över meningen med livet.

"The need for meaning becomes more salient at high levels of existential security so that, even in rich countries, although church attendance is declining, spiritual concerns more broadly are not disappearing" (Norris \& Inglehart 2004 s. 74-75).

Men Inglehart har också visat ett teoretiskt intresse för religiositet i nästa fas i samhällsutvecklingen som han kallar för det postindustriella samhället. Tillsammans med Welzel menar Inglehart att dessa människor - till skillnad från det industriella samhället - i större utsträckning återigen börjar intressera sig för religiösa frågor av andlig natur. Det är dock ett intresse utanför de religiösa institutionernas verksamhet. Vetenskapens begränsningar, ömtåligheten i natur och miljö samt olika sekulära ideologiers tillkortakommanden ligger enligt dem till grund för ett ökat andligt intresse (Inglehart \& Welzel 2007 s. 32). Förvisso presenterar de inga empiriska undersökningar om förändrad religiositet, men ett ökat religiöst intresse av den typ som de beskriver bör betraktas som motsatsen till sekularisering, det vill säga sakralisering: religionens betydelse ökar inom allt fler områden för allt fler människor (Hagevi 2001, 2002, 2007, se också Sjödin 2001).

\section{Teori}

Något som saknas i Ingleharts studier om religiös förändring är att religion och religiositet äger rum på flera olika nivåer i samhället. Religionssociologen Karel Dobbelaere urskiljer tre olika analysnivåer när han studerar religion, religiositet och sekularisering: samhällsnivå, organisationsnivå och individuell nivå (Dobbelaere 1981, 1999, 2002, se också Demker 1998 samt Pettersson 2009 i detta nummer av Socialvetenskaplig Tidskrift). En sådan uppdelning är essentiell när 
religiös förändring (det vill säga såväl sekularisering som sakralisering) studeras. För det första kan den religiösa förändringen vara olika omfattande och gå i olika riktningar på olika nivåer. För det andra kan en religiös förändring på en nivå vara en orsak till religiös förändring på en annan nivå.

Andra forskare skiljer också på olika sorters religiös förändring. De beskriver en religiös marknad där det finns religiöst utbud och efterfrågan (Hamberg 2002, Hamberg \& Pettersson 1994, Pettersson 2009, Stark 1996, Stark \& Bainbridge 1987, Stark \& Finke 1993, Stark \& Iannaccone 1993, 1994). Religiöst utbud berör tro, tillhörighet och beteenden som presenteras av religiösa institutioner som kyrkor och liknande. Denna form av utbud motsvarar vad som tidigare i denna artikel blivit definierat som religion. Religiös efterfrågan är istället individers religiositet. I ett samhälle - eller en religiös marknad - kan det religiösa utbudet variera beroende på konkurrensförhållandena. Enligt teorins upphovsmän antas stark religiös konkurrens leda till att den religiösa efterfrågan tillfredställs i större utsträckning än om ett religiöst monopol föreligger. En stark konkurrens antas dock bara existera vid religiös pluralism - det vill säga att det finns flera religiösa organisationer med olika inriktningar i ett samhälle - och religiös frihet (oreglerad marknad). Ju fler och jämstora de religiösa organisationerna är, desto större är den religiösa konkurrensen. Om däremot samhället domineras av ett samfund - till exempel en statskyrka som dessutom upprätthålls genom att begränsa människors rätt att välja ett annat alternativ (reglerad marknad) - uppstår en monopolsituation.
Utifrån tankegången om en religiös marknad kan ett samhälle som förändras från en monopolsituation till en mindre reglerad marknad med större konkurrens också på ett bättre sätt kunna stimulera den religiösa efterfrågan (Hagevi 2002, 2007, Pettersson 2009 i detta nummer av Socialvetenskaplig Tidskrift). En sådan förändring kan ha tre komponenter. För det första kan staten sekulariseras och bryta kopplingarna till ett dominerande samfund och till exempel avskaffa statskyrkosystemet. För det andra kan fler religiösa organisationer med en allt större variation i religiöst budskap öka den religiösa pluralismen.

För det tredje kan Ingleharts teori om värdeförändring mellan generationer också implicera en religiös förändring. Det är anmärkningsvärt att Inglehart verkar ha glömt bort sin egen teori om en tyst revolution när han studerar religiositet. I korthet utgår Inglehart från två hypoteser. Den första kan kallas för knapphetshypotesen. Den innebär att ett behov tenderar att värderas högre om det råder utbudsbrist på det som tillfredsställer behovet ifråga, jämfört med om utbudet överstiger efterfrågan och det råder överflöd. Den andra hypotesen som Inglehart utgår ifrån är en socialisa tionshypotes: människor tenderar att genom hela sitt vuxna liv ha kvar de värden som de erhållit under uppväxttiden och ungdomsåren. Detta anses vara den tid då de flesta människors grundläggande värden formas. Enligt Inglehart ger dessa båda hypoteser upphov till att olika generationer tenderar att ha olika värden. Han menar att personer som växt upp under materiellt och säkerhetsmässigt otrygga omständigheter tenderar att i förhållandevis stor utsträckning vara 
materialister. De som istället växt upp under materiellt och säkerhetsmässigt trygga förhållanden tenderar att i större utsträckning vara postmaterialister. Allt eftersom samhällen moderniseras menar Inglehart att andelen postmaterialister ökar och andelen materialister minskar (Inglehart 1977).

Låt oss också anta att Inglehart och de religionssociologiska forskningskollegorna har rätt; det religiösa intresset tillhör människans natur. Antag samtidigt att människorna i ett extremt sekulärt samhälle sällan kommer i kontakt med religiösa institutioner eller någon form av religiöst utbud, i alla fall i mycket mindre utsträckning än vad som var fallet någon eller några generationer tidigare. Vad innebär då knapphetshypotesen i förhållande till religion för dem som växer upp i ett extremt sekulärt samhälle? Det minskade utbudet av religion på vad Dobbelaere kallar samhällsnivå och organisationsnivå - samtidigt som den individuella efterfrågan alltjämt finns - borde innebära att tillgången på religion uppfattas som knapp. Bland människor som haft sin formativa uppväxttid under religiös knapphet borde värdet av den lilla religion som finns uppskattas mer. Därmed borde sekularisering på samhälls- och organisationsnivå ha en effekt som Inglehart förbisåg: att betydelsen av religiösa värden ökar, till och med traditionellt kristna värden. Alltså borde betydelsen av religiösa värden öka bland de personer som växt upp i den religiösa knapphetens sekulära samhälle.

\section{Generationer}

Beroende på de omständigheter som var rådande under uppväxttiden är det möjligt att dela in befolkningen i flera generationer. Enligt Inglehart går en vattendelare mellan personer som i huvudsak är uppväxta efter andra världskriget och de som i huvudsak är uppväxta före och under detta krig. De sistnämnda människorna är uppväxta före välfärdsstaternas expansion i Västeuropa och har på olika sätt varit utsatta för krig eller ett påtagligt hot om krig. Denna så kallade förkrigsgeneration har haft en uppväxttid som i betydlig del varit otrygg såäl ekonomiskt som rent fysiskt. Enligt Ingleharts teorier - och de flesta andra som studerat sekularisering - bör förkrigsgenerationen vara mer religiös än yngre generationer.

Den generation som växte upp under de två decennierna närmast efter andra världskriget har på engelska kallats för $B a b y$ Boomers. En svensk benämning på motsvarande generation är raketgenerationen som är födda på 1940- och 1950-talen. Kortfattat kan raketgenerationen beskrivas som den generation som växte upp efter andra världskriget, gjorde uppror år 1968 för att sedan ta universitetsexamen och inleda lysande karriärer som möjliggjorde ett tillrättalagt liv i det välfärdssamhälle som deras föräldrar byggt (Floyd \& Lindqvist 1987).

Generationerna efter andra världskriget har varit föremål för flera indelningar. Vanligtvis delas generationerna in i 20-årsintervaller. Nästa generation är därför född på 1960- och 1970-talen och kallas för generation X (Flory \& Miller 2000, Graber 2001, se även Cox 1998). Det var den kanadensiske designern och författaren Douglas Coupland (1991) som myntade begreppet generation X. Han och även forskarna som anammat hans begrepp antar att personerna 
i denna generation har speciella värderingar, något som Coupland senare har återkommit till i sitt författarskap. I boken Life After God (1994) försöker Coupland ge glimtar av hur det är att vara uppfostrad av raketgenerationen, den första generationen som slutat att tro på Gud. I en av bokens korta noveller rattar bokens berättare på sin bilradio. Han råkar då få in flera kristna radiostationer. Sändningarna är alla fokuserade på Jesus som likställs med vänskap, kärlek och alla andra mänskliga behov. Till detta lyssnar bilföraren som om han försöker dechiffrera ett främmande språk.

Eftersom generationsforskningen blivit allt mer etablerad har det varit många som givit förslag på vad nästa generation - som är födda mellan 1981-2000 - skall kallas och vad som utmärker dem: generation Y, millenniegenerationen, millennianerna är några namnförslag. Det är inte meningen att avge någon generell karaktäristik för denna grupp (om det finns någon), men i fortsättningen kallas de för generation Msom i millennium.

Det finns dock vissa antaganden som kan göras angående vad som utmärker de fyra olika generationernas religiositet och religiösa erfarenheter. Förkrigsgenerationen antas vara den som är mest religiöst intresserad och engagerad i och med att denna generation i minst utsträckning har sekulariserats. Sekulariseringen antas sedan ha accentuerats under den tid då raketgenerationen växte upp. Det var i slutet av denna tid som det extremt sekulära samhället etablerades. Men vad händer med generation X och $\mathrm{M}$ som växt upp i det extremt sekulära samhället? Antingen uppvisar de alltjämt ett lågt religiöst intresse, låt vara att individer undrar över meningen med sitt liv. Eller så innebär den religiösa knappheten och en mer konkurrensutsatt religiös marknad att ett lågt religiöst intresse förbyts till ett ökat religiöst intresse. I så fall kan det mycket väl vara så att generationerna $\mathrm{X}$ och $\mathrm{M}$ tenderar att ha ett större religiöst intresse än raketgenerationen som i sin tur kan vara den mest sekulariserade generationen i dagens extremt sekulära samhälle.

\section{Undersökningen}

Undersökningen genomförs i två steg. För det första beskrivs generationsskillnader angående den religiösa uppväxten. Det sker genom att studera sekularisering på individ-, organisations- och samhällsnivå.

Analyserna på individnivå behandlar om den svenska befolkningen besöker gudstjänster eller andra religiösa möten regelbundet (det vill säga minst en gång i månaden) eller om de överhuvudtaget besöker religiösa möten under ett år. Tanken är att ju större andel i en generation som besöker religiösa möten, desto större inflytande har dessa religiösa institutioner i deras liv. Dessutom, ju mindre inflytande religiösa institutioner har i människors liv, desto mindre engagemang har dessa för att överföra religiösa normer till nästkommande generation. Uppgifterna om religiösa mötesbesök är hämtade från SOMinstitutets undersökningar av den svenska befolkningen mellan 1987-2008 (Holmberg \& Weibull 2009, Nilsson 2009). ${ }^{2}$

På organisationsnivå studeras utbudet

2 SOM står för Samhälle Opinion och Massmedia. 
av religiösa riter (och indirekt normer) och religiös pluralism. Föräldrarna kan markera sina barns passager i livet genom religiösa riter - dop och konfirmation - eller låta familjebildningen ske efter religiösa normer - genom att först gifta sig i kyrkan och sedan bilda familj. I den mån dessa religiösa riter genomförs är det ett tecken på att religiösa normer alltjämt är viktiga i samhället. Det behöver dock inte innebära att människor som deltar i de religiösa riterna är religiösa, utan att de uppfattar att deras omgivning förväntar sig, att de genomgår dessa riter av tradition eller för att upprätthålla normalitet. Även om deltagarna i riterna inte själva betraktar sig som religiösa innebär upprätthållandet av religiösa riter, att det finns sociala normer som gör att individen av plikt och andra skyldigheter deltar i dem. Om dessa religiösa riter istället inte genomförs - inget dop av spädbarn, ingen konfirmation av 15-åringar eller familjebildning utan äktenskap - är det ett tecken på att centrala religiösa normer tappar mark som allmänt accepterade sociala normer och att dessa i allt mindre utsträckning överförs till nästkommande generation.

Religiös pluralism studeras genom att jämföra hur koncentrerad svenska befolkningens samfundstillhörighet är 1930 och 1999. Vid båda tillfällena genomförs sekundäranalys. Dels av uppgifter insamlade av svenska statens folkräkning år 1930, dels av uppgifter insamlade av forskningsprojektet Sverigeräkningen 1999 (Statistiska centralbyrån 1937, Skog 2001).

Angående samhällsnivå beskrivs förändringarna av religionsundervisningen i grundskolan under 1900-talet. Anled- ningen till detta är att religionsundervisningens omfång och dess innehåll - i vad mån den är konfessionell eller samhällsorienterad - indikerar vilken roll religionen spelar för eleverna i samband med undervisningen. Mycket konfessionell undervisning visar på en större roll för religion jämfört med en mer samhällsorienterad undervisning. Eftersom undervisning är central i normöverföring mellan generationer är en allt mindre roll för konfessionell undervisning i grundskolan också ett tecken på minskad religiös normöverföring mellan generationer.

Steg två handlar om att undersöka religiöst intresse över tid och mellan generationer. En frågeundersökning om religiösa värden kan ge sådana indikationer. Tyvärr finns det inte en uppsjö av lämpliga undersökningar att välja bland. Sedan år 1986 har dock SOM-institutet vid Göteborgs universitet undersökt svenska befolkningens uppfattning om hur viktig frälsning är (Holmberg \& Weibull 2009, Nilsson 2009). Ett begrepp av typen frälsning kan förstås på många olika sätt. Utifrån SOM-undersökningen är det inte möjligt att avgöra vad frälsning betyder för svarspersonen. Det är inte alls säkert att en svarsperson associerar till begreppet frälsning på samma sätt som en präst eller pingstvän skulle göra. Det är dock troligt att de flesta anser att begreppet frälsning är associerat med kristendom, det vill säga en av de traditionella religioner som Inglehart inte trodde skulle vara intressant för generation $\mathrm{X}$ och $\mathrm{M}$ (se Hagevi 2005 s. 216). I vad mån människor uppfattar det religiösa värdet frälsning som viktigt kommer därför att användas för att undersöka det religiösa intresset mellan de 
olika generationerna. Ju viktigare frälsning uppfattas vara, desto större uppskattas också det religiösa intresset vara.

Generellt kan skillnader mellan åldersgrupper vara av tre slag. För det första kan skillnader vara knutna till en livscykel, till exempel att man med stigande ålder tenderar att bli allt mer religiös. För det andra kan det röra sig om periodeffekter; en åldersgrupp eller flera åldersgrupper uppvisar av någon anledning (till exempel en dramatisk händelse) högre religiositet än andra. För det tredje kan skillnader vara knutna till generationsförändringar; den yngre generationen är mindre religiös än den äldre och är så livet ut. Vid sekularisering antas den sistnämnda förändringen ha inträffat. Vilken av dessa förändringar som är aktuell kan prövas via kohortanalyser, något som kräver återkommande mätningar under en mycket lång period. Sådana data finns tyvärr inte att tillgå.

De tidsserier som ändå finns är dock tillräckligt omfattande för att det skall vara möjligt att undersöka i vad mån sekularisering i en yngre åldersgrupp överensstämmer med samma process $i$ en äldre åldersgrupp. Därför undersöker jag synen på frälsning bland personer 15-39 år med personer 40-85 år. SOM-institutet har undersökt svenska befolkningens syn på frälsning sedan år 1986 och religiösa mötesbesök sedan år 1987. I mitten av 1980-talet var en hel del av raketgenerationen alltjämt under 40 år och i den yngre åldersgruppen tillhörde då de flesta raketgenerationen. År 2000 hade den siste i raketgenerationen lämnat den yngre gruppen under 40 år samtidigt som endast generation X:s samtliga årskullar fanns inom åldersintervallet
15-39 år. För varje år som går från mitten av 1980-talet till millennieskiftet fasas således raketgenerationen ut och ersätts först av generation X. Sedan inträffar motsvarande utfasning mellan generationerna $X$ och M. På så sätt är det möjligt att undersöka om det religiösa intresset i ålderskategorin 15-39 år ökar eller minskar allt eftersom yngre generationer tar över.

\section{Samhällsnivå}

I det följande redovisas religiös förändring på tre analysnivåer: samhälls-, organisations- och individnivå. Vi börjar med samhällsnivån.

På samhällsnivå innebär sekularisering att religion och politik (i form av staten) separeras $i$ allt större utsträckning. Inte sällan har statens förhållande till religion givet upphov till politiska konflikter. Såväl i Sverige som internationellt har religion varit ett politiskt stridsäpple i samband med utbildning (Demker 1998). Det är således långtifrån en slump att religionens roll i skolan analyseras då grundskolans religionsundervisning länge spelat en viktig roll i utbildningspolitiken.

För förkrigsgenerationen och raketgenerationen var religionsämnet en undervisning i kristen tro, vilket i stor utsträckning var liktydigt med den evangelisk-lutherska läran. Svenska kyrkan hade speciella rättigheter att delta i samband med kristendomsundervisningen ända fram till slutet av 1950-talet. Men under denna tidsperiod och därefter har dock skett stora förändringar av religionsundervisningen i skolan. I det följande beskrivs huvuddragen $i$ ämnets omvandling. 
Fram till år 1919 genomförde den dåvarande folkskolan en ren konfessionell undervisning i statskyrkans lära. Kristendom var det viktigaste ämnet med ungefär tio timmars undervisning i veckan. Sedan inträffar en genomgripande förändring. Med en ny läroplan införs en icke-konfessionell etisk-evangelisk kristendomsundervisning som tilldelas ungefär två undervisningstimmar i veckan. Istället för att som tidigare fokusera på katekesen är Bibeln - speciellt Jesu bergspredikan - huvudlitteratur. Under 1920-talet kom Bibeln att kompletteras med en lärobok i kristen tro. Trots kristendomens framträdande position deklarerade dåtidens undervisningsplan att ämnet också avsåg att främja tolerans gentemot alternativa läror. I samband med införandet av grundskolan år 1962 ersätter kristendomskunskap den gamla beteckningen kristendom. Avsikten var nu inte att lägga grunden för en kristen livsåskådning utan endast orientera eleverna om den kristna tron (Dahlgren 1985, Gustafsson 1991, Straarup 1992).

I slutet av 1960-talet när de första årskullarna i generation X skall börja grundskolan bryts traditionen med kristen undervisning. Redan år 1964 byter kristendomsundervisningen namn till religionskunskap på gymnasiet. Grundskolan följer efter i och med den nya läroplanen år 1969. Enligt denna läroplan är det nya ämnet inte någon undervisning i den kristna tron. Istället betraktas för första gången religionskunskap som ett samhällsorienterande ämne. Läraren skall undervisa om alla de stora världsreligionerna, även om kristendom betonas särskilt (Dahlgren 1985, Gustafsson 1991). Religionsämnet har därmed transformerats från att ha varit en konfessionell undervisning i Svenska kyrkans lära, via icke-konfessionell etisk-evangelisk kristendomsundervisning till multireligiös religionskunskap. ${ }^{3}$

Utbildningen har således genomgått kraftig sekularisering, speciellt under 1960-talet. Från att ha koncentrerat sig nästan uteslutande på att undervisa i kristendom - och propagerat för den - infördes ett samhällsorienterat och multireligiöst undervisningsmoment runt år 1970. Jämfört med tidigare generationer är det en mycket annorlunda undervisning som generation X och M inhämtat. Årskullarna i generation $\mathrm{X}$ var de första som fick gå $\mathrm{i}$ den sekulariserade grundskolan som även generation $\mathrm{M}$ har erfarenhet av. Kunskap $i$ en religion blir sannolikt mindre detaljerad, om undervisningen också inom samma tidsrymd skall ta upp andra religioner. I skolan borde således generation $\mathrm{X}$ och $\mathrm{M}$ ha fătt bredare men grundare kunskap om religion än föregående generationer. Religionens förändrade roll i skolan är därmed en del i det extremt sekulära samhälle där generation $\mathrm{X}$ och $\mathrm{M}$ växt upp.

\section{Organisationsnivå}

På organisationsnivå erbjuder religiösa institutioner och rörelser tro, tillhörighet och levnadssätt. I den mån religiösa riter genomförs i en befolkning är det ett tecken på betydelsen av centrala religiösa normer i

3 Det är möjligt att betrakta det ökande antalet konfessionella friskolor som en avvikelse från den gängse beskrivningen av sekularisering. 
samhället. Om antalet genomförda religiösa riter minskar indikerar det att normöverföringen mellan generationer blir svagare. Det är främst Svenska kyrkan som erbjuder och utför religiösa riter i Sverige: dop, konfirmation, nattvard, vigsel och begravning. Om andelen $i$ en generation som genomgått religiösa riter är förhållandevis liten bör detta vara ett tecken på att de växt upp i ett förhållandevis sekulariserat samhälle. Därmed är det intressant att analysera andelen ogenomförda religiösa riter, det vill säga de fall där religiösa riter inte genomförts fast riterna enligt det dominerande samfundets normer borde ha blivit utförda.

Ogenomförda riter kan också indikera vilken roll religiösa normer spelar för svenskarna. Till exempel är en central religiös norm att familjebildning sker i ett av kyrkan välsignat äktenskap. Att studera andelen utomäktenskapliga barn och borgerliga vigslar ger signaler om hur vanligt det är att på ett förhållandevis klart sätt ställa sig utanför den traditionella religiösa normstrukturen (båda dessa mått är samfundsneutrala). Dessutom rapporteras två mått på riter som Svenska kyrkan inte utfört: spädbarn som inte döpts och 15-åringar som inte konfirmerats i Svenska kyrkan. I Figur 1 redovisas andelen ogenomförda riter 1920-2007.

Enligt Figur 1 har generation X och M växt upp i ett sekulariserat samhälle av aldrig tidigare skådat slag, men däremot inte förkrigsgenerationen och raketgenerationen. Samtliga indikatorer på sekularisering ökar. Det stora brottet då antalet ogenomförda religiösa riter ökar kraftigt inträffar inför och under 1970-talet och ökningen fortsätter under senare årtion- den, det vill säga under de årtionden som generation X och $\mathrm{M}$ växer upp. De förändrade förhållandena runt år 1970 är markanta. I religiöst avseende är det möjligt att tala om ett före och ett efter, ett samhälle där riterna markerar att en viss del av den religiösa normöverföringen är intakt, och ett samhälle som är alltmer sekulärt. Det är således ännu ett tecken på att generation $\mathrm{X}$ och $\mathrm{M}$ under sin uppväxttid formats av förhållandena i ett extremt sekulärt samhälle.

Det är vanligt att konfirmationen äger rum vid 15 års ålder i Svenska kyrkan. Efter kristendomsämnets avskaffande kan konfirmationsundervisningen ses som Svenska kyrkans stora chans att undervisa det uppväxande släktet i sin religion. Den genomförda konfirmationsundervisningen minskar dock kraftigt under 1900-talets sista decennier. År 2007 är nästan två tredjedelar av alla 15-åringar inte konfirmerade av Svenska kyrkan och ökningstakten ser inte ut att mattas av. Det är således inte bara i skolan som utbudet av kristen undervisning minskat, utan den undervisning som sker i Svenska kyrkans regi har också tappat mark i generation X och M. Som kollektiv har generation $\mathrm{X}$ och $\mathrm{M}$ antagligen avsevärt mindre kunskap om kristendom än tidigare generationer.

\section{Religiös pluralism}

På organisationsnivå analyseras även utbud i form av antalet religiösa organisationer. Traditionellt betraktar många forskare en ökad religiös pluralism och andra konkurrerande idéer som en indikator på ökad sekularisering. Det finns främst två skäl 
till detta. För det första antas individer som konfronteras med flera olika religioner (och konkurrerande idéer) att bli förvirrade och osäkra på sitt ursprungliga trossystem (Berger 1967, Dobbelaere 1981, 1999, 2002, Voyé 1999). Inga empiriska undersökningar stödjer dock detta antagande (Norris \& Inglehart 2004). För det andra förutsätts att religiös pluralism minskar det sociala trycket att utöva religion och gör det lättare att bryta med religiös tradition och välja en sekulär livsstil (Dobbelaere 1981, 1999, 2002, Luhmann 1977). Detta är inte heller något självklart antagande. I ett extremt sekulariserat samhälle där det inte finns någon religion som dominerar kan istället en ökad religiös pluralism - även om den är liten - stimulera

Figur I.

Indikatorer på sekularisering: ogenomförda religiösa riter 1920-2007.

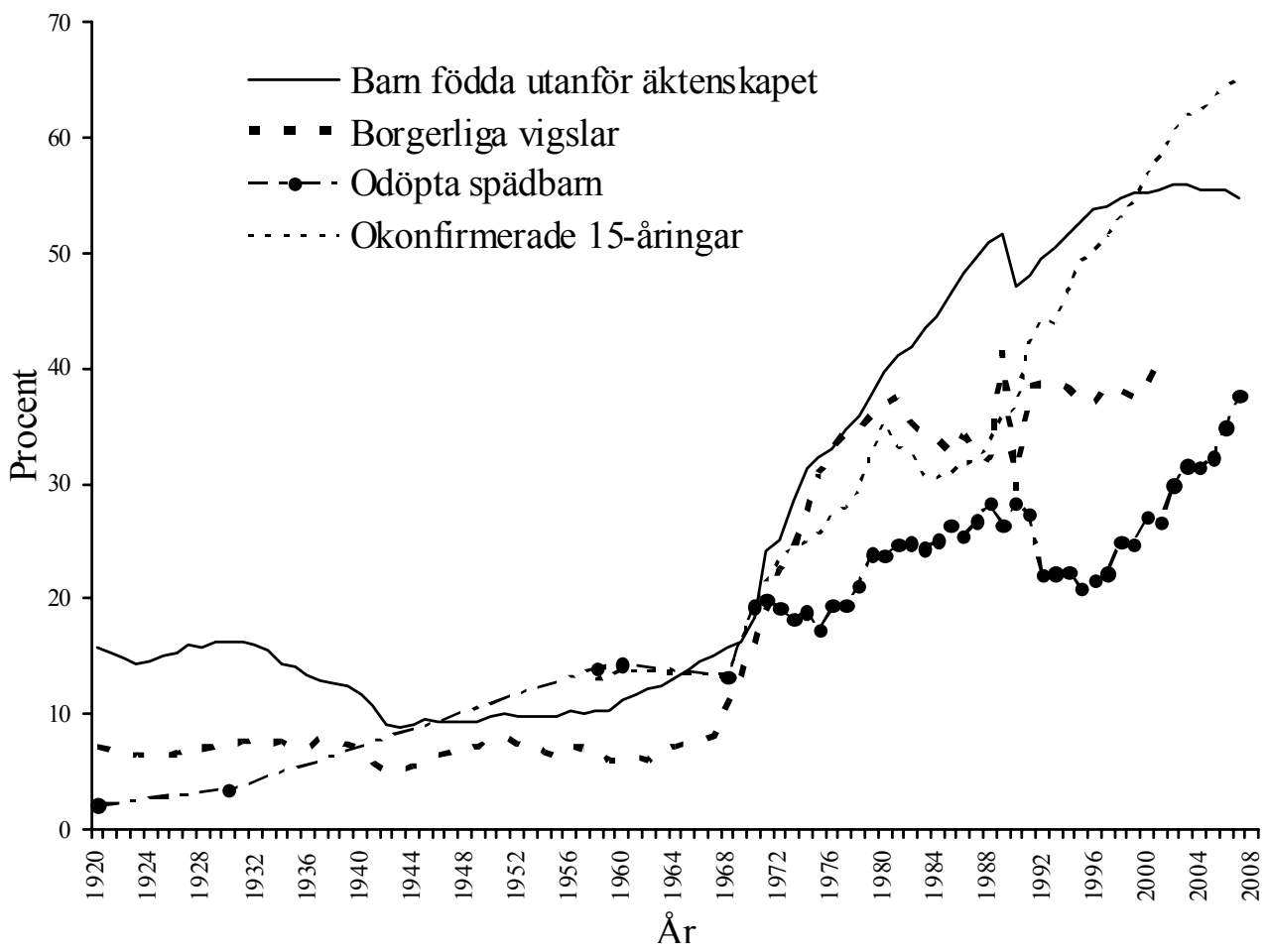

Utomäktenskapliga födda barn avser procent av samtliga levande födda. Borgerliga vigslar avser procent av samtliga vigslar. Okonfirmerade 15-åringar avser procent personer som inte har konfirmerats i Svenska kyrkan det år som de fyller 15 år. Odöpta spädbarn avser procent av under året födda barn som inte döpts av Svenska kyrkan. Angående döpta spädbarn och konfirmerade år 1970-2007 är uppgifterna hämtade från Svenska kyrkan 2009. Angående döpta spädbarn och konfirmerade år 1960 och 1968 är uppgifterna hämtade från Stoltz 1970 s. 22. Övriga uppgifter är hämtade ur Statistiska centralbyrån 1925 s. 16, 1937 s. 6-8, 1969 s. 96-99, 1992 s. 47, 2009 s. 91. Observera att mellan år 1930-1958 finns inga mätpunkter registrerade angående odöpta spädbarn. 
religiöst intresse (Hamberg 2002, Hamberg \& Petterson 1994, Pettersson 2009).

Vid studier av svensk religiös pluralism är medlemsutvecklingen i Svenska kyrkan en lämplig utgångspunkt. Medlemstalen i Svenska kyrkan är fallande. År 1972 var mer än 95 procent av den svenska befolkningen medlemmar i Svenska kyrkan. År 1995 hade motsvarande andel fallit till 86 procent och år 2000 till 83 procent. År 2007 var andelen av svenska befolkningen som var medlemmar i Svenska kyrkan nere i 74 procent. Denna nedgång är ett exempel på sekularisering och hur ett samfunds dominerande roll i ett samhälle minskar. Utvecklingen öppnar också upp för ökad religiös pluralism. Det svenska religiösa utbudet kommer i allt större utsträckning från andra organisationer än Svenska kyrkan, inte minst genom ökad invandring (Hagevi 2009). Herfindahls index (H) är ett mått på graden av koncentration där 0 visar låg koncentration och 1 på hög koncentration. Detta kan användas för att beräkna religiös pluralism där lågt $\mathrm{H}$ visar på hög pluralism (att befolkningen är spridd på flera religiösa samfund) och högt $\mathrm{H}$ visar på låg pluralism (att befolkningen till stor del är koncentrerade till få religiösa samfund). För 1930 är $\mathrm{H}=0,87$ och för 1999 är $\mathrm{H}=0,66$ (beräkningen baseras på data från Statistiska centralbyrån 1937 och Skog 2001). Detta visar att den religiösa pluralismen har ökat mellan 1930 och 1999.

Slutsatsen är att Svenska kyrkans dominerande roll som religiös institution minskar och att svenska befolkningen har blivit väsentligt mer religiöst heterogent under senare delen av 1900-talet.

\section{Individnivå}

Ett tecken på individuell sekularisering är ett minskat religiöst engagemang. Som indikator på individens religiösa engagemang används vanan att besöka gudstjänst eller religiöst möte. Tidigare forskning har visat att förhållandevis få dyker upp på söndagsgudstjänsten i Sverige. Andelen är bland den lägsta i världen och har dessutom minskat över tid. Under det andra världskriget gick var femte svensk regelbundet (det vill säga minst en gång i månaden) på gudstjänst. År 2006 noterades bottennoteringen sju procent regelbundna kyrkobesökare (Oscarsson \& Holmberg 2008).

SOM-institutet började undersöka religiösa mötesbesök år 1987. Svarspersonen har kunnat ange något av sju fasta svar: från att under de senaste tolv månaderna aldrig besökt religiösa möten till att ha besökt religiösa möten flera gånger i veckan. Att aldrig ha besökt religiösa möten innebär 0 besök, medan en person som uppger sig ha besökt religiösa möten flera gånger i veckan har gjort minst 104 besök. På motsvarande sätt kan minsta antalet besök beräknas för övriga möjliga svar (se kommentar till Figur 2). I Figur 2 redovisas medelvärdet av antalet uppgivna årliga religiösa mötesbesök mellan 1987-2008. Förändringen över tid redovisas i två åldersgrupper: yngre personer som vid undersökningstillfället var mellan 15-39 år jämförs med äldre personer som var mellan 40-75/85 år.

Vad gäller religiösa mötesbesök ökar sekulariseringen alltjämt. I båda ålderskategorierna minskar antalet besök av religiösa möten. Personer under 40 år besöker religiösa möten mer sällan än personer som 
är 40 år eller äldre. Över tid är skillnaden mellan de båda ålderskategorierna förhållandevis stabil.

Vad säger då det genomsnittliga antalet besök av religiösa möten om kyrkor och andra religiösa organisationers betydelse för människor i olika generationer? För det första att kyrkor och liknande har tappat mycket av sina möjligheter att påverka. En mycket liten del av svenska befolkningen tar del av deras budskap på regelbunden basis. För det andra tenderar både generation $\mathrm{X}$ och $\mathrm{M}$ att ha erfarenhet av föräldrar som besökte religiösa möten i mindre utsträckning än vad mor- och farföräldrar gjorde.

\section{Sammanfattning}

Sedan 1970-talet har det skett en omfattande sekularisering på individnivå, orga-

\section{Figur 2.}

Antal besök av religiösa möten under de senaste 12 månaderna efter ålder 1987-2008 (medelvärde).

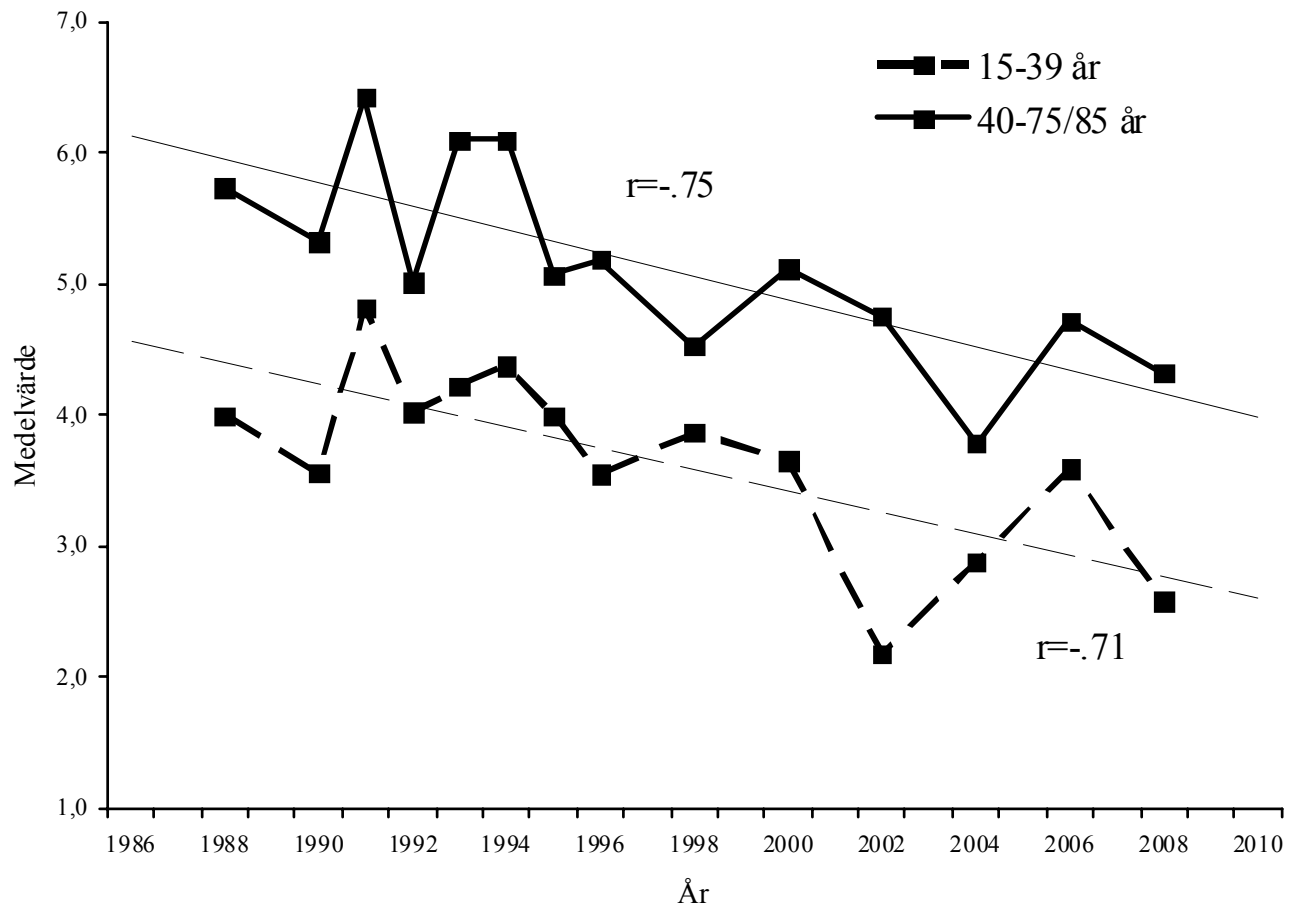

Frågans formulering är Hur ofta har Du under de senaste 12 månaderna gjort följande saker? varefter bland annat Besökt gudstjänst eller religiöst möte nämns. Svarsmöjligheterna är Ingen gång (kod=0), Någon gång under de senaste 12 månaderna ( $\mathrm{kod}=1)$, Någon gång i halvåret $(\mathrm{kod}=2)$, Någon gång $i$ kvartalet $(\mathrm{kod}=4)$, Någon gång i månaden (kod=12), Någon gång i veckan ( $k$ d=52) och Flera gånger $i$ veckan $(k o d=104)$. Mellan år 1986-1991 var den övre åldersgränsen i SOM-undersökningarna 75 år, mellan år 1992-1999 var den övre åldersgränsen 80 år och från och med år 2000 var den övre åldersgränsen 85 år. 
nisationsnivå och samhällsnivå. På individnivå visar allt färre människor ett religiöst engagemang genom att besöka religiösa möten. På organisationsnivå förblir många religiösa riter ogenomförda. På denna nivå ökar dock den religiösa pluralismen, en form av sakralisering. På samhällsnivå tilltar separationen mellan kyrka och stat. På organisations- och samhällsnivå ökar sekulariseringen extra mycket runt 1970. Då börjar andelen i befolkningen som genomför traditionella religiösa riter minska, vilket indikerar ett brott i den religiösa normöverföringen. Ett fåtal av deras föräldrar besöker en kyrka regelbundet. Kristendomsundervisningen är avskaffad och ersatt av samhällsorienterad religionskunskap. Deras föräldrar är inte gifta i kyrkan och de själva är ofta odöpta och framförallt okonfirmerade. Samtidigt har den religiösa pluralismen ökat i det svenska samhället. Det är således möjligt att generation $\mathrm{X}$ och $\mathrm{M}$ - till skillnad från förkrigsgenerationen och raketgenerationen - formats av ett extremt sekulärt samhälle, men också ett samhälle som fått ökad religiös frihet och fler religiösa aktörer. Detta kan beskrivas som en avreglerad religiös marknad med ökad konkurrens som antas stimulera efterfrågan på religion, det vill säga individers religiositet. Samtidigt kan generation $\mathrm{X}$ och $\mathrm{M}$ betraktas som "svältfödda" på religion. Enligt Ingleharts knapphetshypotes - att folk värderar något högre om tillgången på det är knapp än om det råder överflöd - är det därför möjligt att generation $\mathrm{X}$ och $\mathrm{M}$ uppfattar religiösa värderingar som allt mer betydelsefulla. Nästa steg i undersökningen är att ta reda på om detta kan stämma.

\section{Religiösa värden}

Generation X och M har till skillnad från förkrigsgenerationen och raketgenerationen växt upp i ett extremt sekulariserat samhälle. Vad innebär det för de olika generationernas religiösa intresse? Sedan år 1986 har SOM-institutet undersökt hur viktig frälsning uppfattas vara bland den svenska befolkningen. Antagandet är att ju viktigare frälsning uppfattas vara, desto större beräknas också det religiösa intresset vara. Frågan är om det religiösa intresset i ålderskategorin 15-39 år ökar eller minskar allt eftersom generation $\mathrm{X}$ och sedermera generation $\mathrm{M}$ tar över?

De svarande har fått ange om de tycker att frälsning är mycket viktigt, ganska viktigt, varken viktigt eller oviktigt, inte särskilt viktigt eller inte alls viktigt. Genom att ge den första svarsmöjligheten (mycket viktigt) värdet 5 , nästkommande värdet 4 och sedan i en fallande skala till den sistnämnda svarsmöjligheten (inte alls viktigt) som får värdet 1 kan ett medelvärde för samtliga svarande i respektive åldersgrupp beräknas. Ju högre medelvärde, desto större betydelse har frälsning för de svarande. Förändringen över tid av betydelsen av frälsning redovisas i Figur 3. Återigen består den yngre gruppen av personer som vid undersökningstillfället var mellan 15-39 år och den äldre av personer som var 40-75/85 år.

För betydelsen av frälsning innebär generation X:s och M:s intåg på arenan en förändring. År 1986 består gruppen under 40 år till största delen av raketgenerationen. Då tenderar också yngre att betrakta frälsning som oviktigare än vad äldre gör, 
något som överensstämmer med tanken om en fortgående sekularisering mellan generationer. Men det som överraskar är att den fortsatta trenden bryter mot antagandena om en allt mer tilltagande sekularisering. Allt fler i den yngre ålderskategorin uppfattar nämligen frälsning som allt viktigare. Då raketgenerationen åldras och flyttas över till den äldre åldersgruppen för att i den yngre åldersgruppen ersättas av generation $\mathrm{X}$ blir frälsning viktigare för personerna under 40 år. När det är dags att ersätta de äldsta årskullarna av generation X med nya årskullar från generation M i den yngre åldersgruppen fortsätter ökningen. I det extremt sekulära samhäl-

\section{Figur 3.}

Hur viktigt är frälsning för Dig? En femgradig skala från »inte alls viktigt« (1) till »mycket viktigt« (5) år 1986-2008 (medelvärde).

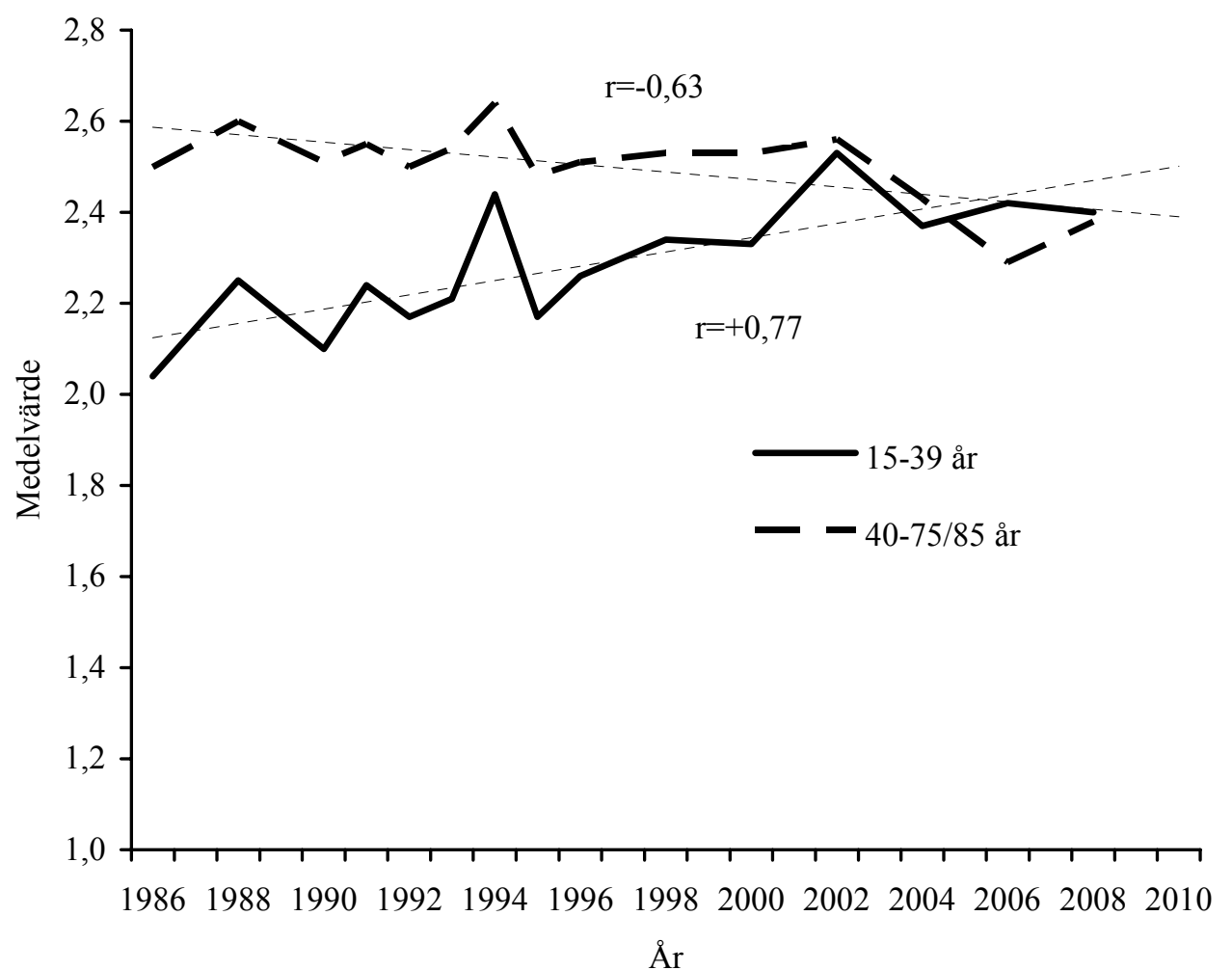

Frågan löd: Hur viktigt tycker Du att följande saker är för Dig? varefter bland annat Frälsning nämndes. Svarsmöjligheterna var Mycket viktigt ( $\mathrm{kod}=5)$, Ganska viktigt ( $\mathrm{kod}=4)$, Varken viktigt eller oviktigt (kod=3), Inte särkilt viktigt (kod=2) och Inte alls viktigt (kod=1). Mellan år 1986-1991 var den övre åldersgränsen i SOM-undersökningarna 75 år, mellan år 1992-1999 var den övre åldersgränsen 80 år och från och med år 2000 var den övre åldersgränsen 85 år. 
let hejdas således inte utvecklingen, utan i den yngre generation $\mathrm{M}$ tenderar frälsning uppfattas som viktigare än i generation $X$. Däremot är betydelsen av frälsning i den äldre gruppen till en början mer stabil, men försvagas plötsligt efter år 2000. Förändringarna är så kraftiga att frälsning uppfattas som viktigare i den yngre åldersgruppen än i den äldre från och med år 2006. ${ }^{4}$

Hur skall tendensen att yngre generationer uppfattar frälsning som allt viktigare förstås? Det är rimligt att tolka uppfattningen om frälsning i ett brett perspektiv, bredare än enbart begreppets kristna betydelse. Sannolikheten att det i generation $\mathrm{X}$ och $\mathrm{M}$ finns en akut frälsningsnöd som tidigare generationer inte känt av är mycket liten. Istället bör resultatet ses som ett ökat intresse för religion i stort. Förvisso ingår då också ett intresse för kristendom och begrepp som frälsning, men antagligen finns också ett ökat intresse för andra religiösa värden och begrepp. Det är därför mer godtagbart att tolka denna förändring som att generation $\mathrm{X}$ och $\mathrm{M}$ för med sig ett ökat generellt intresse för religiositet än något annat. Detta är en form av sakralisering, vilket skall förstås som motsatsen till sekularisering: religion blir viktigare inom allt fler områden för allt fler människor.

I den heldragna kurva som representerar den yngre gruppen under 40 år finns tre plötsliga hopp uppåt som strax efteråt möter en rekyl nedåt. De inträffar år 1988, 1994 och 2002. De första två är san-

4 Resultatet kvarstår även när personer med utländsk bakgrund (första och andra generationens invandrare) exkluderas från analysen. nolikt en reaktion på uppmärksammade katastrofer som påverkar de svarande, ett fenomen som även noterats i andra undersökningar (Två undersökningar om Estonia och religionen 1995, jfr. Källstad et al. 1986). År 1988 inleddes SOM-undersökningarnas fältarbete någon månad efter det att en svår bussolycka inträffat i Norge. De flesta av dem som omkom var barn från Kista i Sverige. Olyckan berörde många djupt och massmedia bevakade händelsen intensivt. Vid rapporteringen av bussolyckan uppmärksammas för första gången på allvar den krishantering som numera är vanlig vid liknande tragedier. Vid denna krishantering spelade kyrklig personal en viktig roll, vilket också rönte uppmärksamhet. År 1994 inleddes SOM-undersökningens fältarbete ungefär vid samma tidpunkt som färjan Estonia förliste i Östersjön. Det är troligt att båda katastroferna återspeglas i ett ökat intresse för frälsning. År 2002 har terrordådet den 11:e september ägt rum ett år tidigare i USA. Det finns också hot om fler terrordåd. Även detta tycks resultera i att frälsning uppfattas som viktigare. Den religiösa reaktionen av denna typ kan vara tämligen kortvarig. Det illustreras av att medelvärdet för betydelsen av frälsning återgår till en mer normal nivå strax efter de olyckliga och katastrofala händelserna.

Även i den äldre åldersgruppen noteras vid samma tidpunkter små hopp uppåt (möjligtvis med undantag av år 2002). Reaktionerna på de tragiska händelserna är dock mer modesta (måhända döljs en reaktion år 2002 av en allmän nedgångstendens). 


\section{Slutsatser}

Resultatet av denna studie säger oss en del om varför raketgenerationen blev så sekulär. De indikatorer på religiös normöverföring som redovisats i denna artikel tyder på att raketgenerationen fick ta del av samma religiösa utbud som sina föräldrar i förkrigsgenerationen. Samtidigt ändrades samhället genom att välfärdsstaten expanderade och krig i Västeuropa kändes allt mer avlägset. Detta är grunden i det som Inglehart kallar värdeförändring mellan generationer. Att det religiösa utbudet inte beaktade denna förändring kan ha varit ödesdigert för det religiösa intresset i raketgenerationen. Religion uppfattades troligen som otidsenliga konventioner, tvång och pålagor. Runt 1970 brast fördämningarna och raketgenerationen gjorde sig kvitt det som många tyckte var ett tomt skal av religiösa normer som fanns i samhället och beredde vägen för ett extremt sekulärt samhälle.

Denna studie kan också till viss del förklara varför generationer som växt upp i ett extremt sekulärt samhälle har ett större intresse för religion än raketgenerationen. Detta tar då sin utgångspunkt i teorin om en religiös marknad med religiöst utbud och efterfrågan. För det första innebar sekulariseringen på samhälls- och organi- sationsnivå att en fri religiös marknad etablerades. Grunden i detta var raketgenerationens brott med religiös normöverföring och att traditionella religiösa institutioner som Svenska kyrkan marginaliserades. För det andra tillkom en ökad religiös konkurrens allteftersom den religiösa pluralismen ökade i det svenska samhället. Till detta (som inte tagits upp i denna artikel) kan läggas en information i massmedia från andra länder om religionens globala roll. Detta förstärker också den religiösa pluralismen. För det tredje tycks det för generation $\mathrm{X}$ och $\mathrm{M}$ ha uppstått en brist i tillgången på religion. Utifrån tanken att det finns ett religiöst behov hos människor kan det extremt sekulära samhället innebära att detta behov inte tillfredsställs. Istället råder brist på adekvat religiöst utbud. När efterfrågan överstiger utbudet ökar värdet, vilket i detta fall innebar ett ökat intresse för religion.

Det finns dock undantag i tanken på en sakralisering bland individer i det extremt sekulära samhället. Det finns ingen vändpunkt i sikte angående religiöst beteende. I detta kapitel har religiösa mötesbesök studerats. Det finns inga tecken på att generation X:s och M:s ökade intresse för religion leder dem till kyrkorna eller andra religiösa byggnader. 


\section{Referenser}

Berger, Peter (1967) The Sacred Canopy: Elements of A Sociological Theory of Religion. Garden City: Doubleday.

Coupland, Douglas (1991) Generation X. Tales For An Accelerated Culture. New York: St Martin's Press.

Coupland, Douglas (1994) Life After God. London: Simon \& Schuster.

Cox, Kristoffer (1998) GenX and God. A GenX Perspective. Chanhassen: Tekna Books.

Dahlgren, Curt (1985) „Sverige». I Göran Gustafsson (red.) Religiös förändring i Norden. Malmö: Liber förlag.

Demker, Marie (1998) Religion och politik. Stockholm: SNS-förlag.

Dobbelaere, Karel (1981) "Secularization: A Multi-Dimensional Concept». Current Sociology, vol. 29, pp. 1-216.

Dobbelaere, Karel (1999) "Towards an Integrated Perspective of the Process Related to the Descriptive Concept of Secularization«. Sociology of Religion, vol. 60, pp. 229-247.

Dobbelaere, Karel (2002) Secularization: An Analysis at Three Levels. Gods, Humans, and Religions: 1. Bryssel: P.I.E.-Peter Lang.

Flory, Richard \& Donald Miller (red.) (2000) GenX Religion. New York: Routledge.

Floyd, Carmilla \& Lindqvist, Marita (1987) Hårda bud. Handbok för 60-talister. Stockholm: Bonniers.

Graber, Doris (2001) Processing Politics. Learning from Television in the Internet Age. Chicago: Chicago University Press.

Gustafsson, Göran (1991) Tro, samfund och samhälle. Sociologiska perspektiv. Örebro: Libris.

Hagevi, Magnus (2001) "Sakralisering efter sekularisering?" I Sören Holmberg \& Lennart Weibull (red.) Land, Du välsignade? SOM rapport:26. Göteborg: Göteborgs universitet, SOM-institutet.

Hagevi, Magnus (2002) "Religiositet i generation X." I Henrik Oscarsson (red.) Spår i framtid. SOM rapport:28. Göteborg: Göteborgs universitet, SOM-institutet.

Hagevi, Magnus (2005) „Sekularisering, vila i frid.»
I Magnus Hagevi (red.) Religion och politik. Malmö: Liber.

Hagevi, Magnus (2007) »De postsekulära generationerna.» I Sören Holmberg \& Lennart Weibull (red.) Det nya Sverige: Trettiosju kapitel om politik, medier och samhälle. SOM rapport:41. Göteborg: Göteborgs universitet, SOM-institutet.

Hagevi, Magnus (2009) Politisk opinion och religiositet i Västra Götaland. Lund: Sekel Bokförlag.

Hamberg, Eva (2002) „Utbud och efterfrågan på religiösa 'marknader'." I Curt Dahlgren, Eva Hamberg \& Thorleif Pettersson (red.) Religion och sociologi; ett fruktbart möte. Religio:55. Lund: Lunds universitet,Teologiska institutionen.

Hamberg, Eva \& Pettersson, Thorleif (1994) »The Religious Market: Denominational Competition and Religious Participation in Contemporary Sweden." Journal for the Scientific Study of Religion, vol. 33, pp. 205-216.

Holmberg, Sören \& Weibull, Lennart (red.) (2009) Svensk höst: Trettiotre kapitel om politik, medier och samhälle. SOM rapport:46. Göteborg: Göteborgs universitet, SOM-institutet.

Iannaccone, Laurance \& Finke, Roger (1997) "Deregulating Religion: The Economics of Church and State." Economic Inquiry, vol. 35, pp. 350-364.

Inglehart, Ronald (1977) The Silent Revolution. Changing Values and Political Styles Among Western Publics. Princeton: Princeton University Press.

Inglehart, Ronald (1990) Culture Shift in Advanced Industrial Society. Princeton: Princeton University Press.

Inglehart, Ronald (1997) Modernization and Post modernization. Cultural, Economic, and Political Change In 43 Societies. Princeton: Princeton University Press.

Inglehart, Ronald \& Welzel, Christian (2007) Modernization, Cultural Change, and Democracy: The Human Development Sequence. Cambridge: Cambridge University Press.

Källstad Thorvald, Ejerfeldt Lennart \& Straarup

Magnus Hagevi: Efter sekulariseringen: förändrade... 
Jørgen (1986) Religiösa reaktioner på Olof Palmes död. Religionsbeteendevetenskapliga perspektiv. Religion och samhälle. Nr 10. Stockholm: Religionssociologiska institutet.

Luhmann, Niklas (1977) Funktion der Religion. Frankfurt: Suhrkamp.

Nilsson, Åsa (2009) „Den nationella SOM-undersökningen 2008.«I Sören Holmberg \& Lennart Weibull (red.) Svensk höst: Trettiotre kapitel om politik, medier och samhälle. SOM rapport:46. Göteborg: Göteborgs universitet, SOM-institutet.

Norris, Pippa \& Inglehart, Ronald (2004) Sacred and Secular: Religion and Politics Worldwide. Cambridge: Cambridge University Press.

Oscarsson, Henrik \& Holmberg, Sören (2008) Regeringsskifte: Väljarna och valet 2006. Stockholm: Norstedts Juridik.

Pettersson, Thorleif (2009) „Religion och samhällspraktik: En jämförande analys av det sekulariserade Sverige." Socialvetenskaplig tidskrift, vol. 16, nr 3-4, s. 233-264.

Sjödin, Ulf (2001) Mer mellan himmel och jord? Stockholm: Verbum.

Skog, Margareta (red.) (2001) Det religiösa Sverige: Gudstjänstliv- och andaktsliv under ett veckoslut kring millennieskiftet. Örebro: Libris.

Stark, Rodney (1996) „Why Religious Movements Succeed or Fail: A Revised General Model." Journal of Contemporary Religion, vol. 11, pp. 133-146.

Stark, Rodney \& Bainbridge, William Sims (1987) A Theory of Religion. Toronto Studies in Religion:2. New York: Peter Lang.

Stark, Rodney \& Roger Finke (1993) "A Rational Approach To the History of American Cults And Sects." Religion and Social Order, vol. 3A, pp. 109-125.

Stark, Rodney \& Iannaccone, Laurence (1993) "Rational Choice Propositions About Religious Movements." Religion and Social Order, vol. 3A, pp. 241-261.

Stark, Rodney \& Iannaccone, Laurence (1994) »A Supply-Side Reinterpretation of the 'Secular- ization' of Europe." Journal for the Scientific Study of Religion, vol. 33, pp. 230-252.

Statistiska centralbyrån (1925) Folkräkningen den 31 december 1920. II. Befolkningsagglomerationer, trosbekännelse, stamskillnad, utrikes födelseort, främmande statsborgarskap, lyten $m . m$. Stockolm: P. A. Norstedts \& Söner.

Statistiska centralbyrån (1937) Folkräkningen den 31 december 1930. V. Trosbekännelse. Främmande stam. Främmande språk m. m. Stockolm: P. A. Norstedts \& Söner.

Statistiska centralbyrån (1969) Historisk statistik för Sverige: Del 1. Befolkning 1720-1967. Stockholm: Allmänna förlaget.

Statistiska centralbyrån (1992) Statistisk årsbok 92. Örebro: Statistiska centralbyrån.

Statistiska centralbyrån (2009) Statistisk årsbok för Sverige 2009. Stockholm: Statistiska centralbyrån.

Stoltz, Ingemar (1970) "Attityder till kristendom och kyrka." I Ingmar Ström, Ingmar Stoltz \& P-O Nilsson En kraftig uppryckning av kyrkan? Gallupundersökningen. Stockholm: Verbum.

Straarup, Jørgen (1992) "Inledning." I Jørgen Straarup (red.) Religionsfrihet och folkkyrka: Jurister, samhällsvetare och teologer om ändrade relationer mellan stat och kyrka. Religion och samhälle:74. Tro \& Tanke 92:3. Stockholm: Svenska kyrkans forskningsråd.

Svenska kyrkan (2009) „Döpta, konfirmerade, vigda och begravda enligt Svenska kyrkans ordning år 1970-2007." Internet: http://www.svenskakyrkan.se/default. aspx?di=23758\& refdi=23673 (Hämtat 200902-28).

Två undersökningar om Estonia och religionen (1995) Lund: Lunds universitet, Teologiska institutionen.

Voyé, Liliane (1999) "Secularization in a Context of Advanced Modernity." Sociology of Religion, vol. 60, pp. 275-288.

Woodhead, Linda \& Heelas, Paul (2000) Religion in Modern Times. Oxford: Blackwell Publishers. 


\section{Summary}

\section{After secularization: Changing religious values between generations}

The study focuses on religiosity in an extremely secular society: the case of Sweden. It examines secularization at three levels: societal, organizational, and individual level. The main data are surveys of the adult Swedish population 1986-2008 and official statistics collected by Statistics Sweden and the Church of Sweden from
1920 to the present. The result shows that people born after 1960 express a stronger interest in religion than people born in the 1940s and 1950s. However, this is a psychological interest. Between these generations, there is no report of increased level of religious behaviour. 